\title{
Téoros
}

Revue de recherche en tourisme

\section{Travels in Everyday Space}

\section{Lesbian Desire along Montréal's Frontier}

\section{Julie Podmore}

Volume 19, numéro 2, été 2000

Le tourisme des gais et des lesbiennes

URI : https://id.erudit.org/iderudit/1071962ar

DOI : https://doi.org/10.7202/1071962ar

Aller au sommaire du numéro

Éditeur(s)

Université du Québec à Montréal

ISSN

0712-8657 (imprimé)

1923-2705 (numérique)

Découvrir la revue

Citer cet article

Podmore, J. (2000). Travels in Everyday Space: Lesbian Desire along Montréal's

Frontier. Téoros, 19(2), 36-40. https://doi.org/10.7202/1071962ar d'utilisation que vous pouvez consulter en ligne.

https://apropos.erudit.org/fr/usagers/politique-dutilisation/ 


\section{Travels in Everyday Space}

\section{Lesbian Desire along Montréal's Frontier}

\section{Julie Podmore}

The relationship between lesbians and the production of urban space is a subject matter wrought with ambiguity. While gay male enclaves are often easily identified, lesbians are often the least visible subcultural group in the urban landscape because their enclaves, neighborhoods, and institutions are imperceptible to outside observers (Adler and Brenner, 1992; Peake, 1993; Valentine, 1995).

At the same time, patterns of spatial concentration among lesbians have been demonstrated through a handful of neighborhood studies (Bouthillette, 1998; Rothenberg, 1995). These studies show that lesbian neighborhoods have particular characteristics (low rents, a flexible housing stock, socially and culturally diverse populations), and that they constitute a relatively small proportion of the resident population. These studies also suggest that because lesbians rarely produce commercial enclaves near their homes, the shared public spaces of their neighborhoods are meaningful sites of social interaction, community building, and identity (Bouthillette, 1998; Rothenberg, 1995). Because there is so little "lesbian space" in the city, lesbians make use of parks and streets, large shopping corridors and "lesbian friendly" businesses such as cafes and restaurants located within these neighborhoods for the expression of their subjectivity and desire.

This paper presents a case study of how lesbians use and interpret Boulevard SaintLaurent, a neighborhood shopping street and important axis of identity in inner-city Montréal. It argues that neighborhood shopping streets are particularly important sites for the expression of lesbian desire and subjectivity. The heterogeneity of shared public spaces such as Boulevard Saint-Laurent not only provides a certain level of anomie, but also leaves room for exploration, experimentation, and "difference" from broader norms of gender and sexuality. Lesbian interactions with this space are characterized as a form of tourism lived in an everyday local context. Like the broader tourist experience, their everyday travels along this street involve displacement, exploration, and self-discovery through interactions with each other and with the broader diversity of the populations along the street.

I begin by setting-up a framework for analysis by drawing upon literary works that have used urban space to contest and revise heteropatriarchal society. Focusing specifically on the works of Québec writer Nicole Brossard, I argue that the mobility of social contact along city streets provides an important means of subverting the heteropatriarchal ordering of space that renders lesbian subjectivity invisible in the urban landscape. Next, I use ethnographic narratives to investigate how lesbian subjectivity and desire are mobilized in urban space. Eighteen semi-directed interviews were conducted in 1996 and 1997 with lesbians who live in the Plateau MontRoyal District. Using a snowball sampling method, I interviewed a highly integrated network of lesbians that included Anglophone, Francophone, and Allophone women between twenty-five and forty years of age, who openly identified as lesbians or bisexuals, and actively participated in lesbian or queer community life. The sample population had very particular characteristics that distinguished them from other lesbians in Montréal: they were primarily students, artists, or in the early stages of professional careers, most were well educated, all were tenants and lived either alone, with roommates or with a lover, and only one had children.

\section{LA VILLE FRONTIÈRE}

According to Gould (1982), feminist literature since the 1970 s has often used the city as a metaphor for patriarchal oppression, and many Québec feminist writers of the period saw the city in similar terms. Accepting that the city was the ultimate site of capitalism and patriarchy, they depicted their female characters as overwhelmed by, and "outside" of, patriarchal urban space. Women were positioned as tourists in the city, voyaging through the terrain of the masculine "other." This current in literature was mirrored in feminist critiques in the environmental sciences during the 1970s and 1980s (Rose 1993). In the 1980s, however, the relationship between women and urban life was complexified as environmental scientists, historians, and even political philosophers pointed toward the city's dual role in women's oppression and liberation (Wekerle, 1980; Wilson, 1991; Young, 1990). In response to women's confinement to suburban environments and the 
essentialist view of the city as "masculine space," some feminists began to argue that "A woman's place is in the city" (Wekerle, 1980). Wilson (1991), in particular, insisted that cities were never solely patriarchal and stressed the importance of the urban experience for women's liberation from the bounds of the private sphere. This theme became particularly pronounced among queer and lesbian authors (Golding, 1993; Munt, 1995), wherein the heterogeneity of city life served as a counter ideal to the rural separatism of earlier decades. The negative view of the "Woman as tourist" in the masculine space of the city was turned on its head. The mobility of urban life and women's voyages into urban space were seen as sources of possibility for the development of autonomous female sexualities (Wilson, 1991).

This more complex notion of the city as a paradoxical space was present in the work of Québec author Nicole Brossard during the 1970s and 1980s (Potvin, 1995). Brossard used language to destabilize the form, relations of power, and structure of the city (Forsyth, 1988; Potvin, 1995). Potvin (1995) describes the city in Brossard's works from that period as $l a$ ville frontière, a fragmented city full of ruptures of possibility. For Brossard, this was a textual strategy employed to disrupt the structures of the heteropatriarchal city and insert a mobile female subject. In response to the feminist interpretation of the city as a site where patriarchal relations of objectification and exploitation constantly immobilize women in public space, Brossard used the constant movement of women to contest heteropatriarchal relations. Driving cars, walking the streets and descending into the metro, she and her characters map their own city (Brossard, $1973 ; 1974 ; 1980)$. This was not, however, an attempt to argue that women have no "place" in the city. La ville frontière was a much more utopian vision of freedom and possibility. As travelers in urban space, women avoid the fixed identities that are proscribed by heteropatriarchal relations and are free to experience and desire in space on their own terms. But Brossard's project was not only deconstruction. Her writings also provide a vision of the city as it is inhabited by those on the margins of heteropatriarchal relations. As Gould (1982) has argued, they were attempts to demonstrate "[...] l'espace réel de la ville habité autrement".
Like Brossard, I seek to alter established notions of urbanity by inserting a mobile female subject. In literary accounts of lesbian subjectivity and space, the city serves primarily as a metaphor for diversity and possibility (Munt, 1995). While my project has a similar objective, as an ethnographic account it is an attempt to ground these spatial metaphors in a particular urban public space. My project also differs from most other studies of lesbians and urban life because it focuses on a street-a public and shared space-rather than on domestic or specifically lesbian space. But streets are conflictive sites for women, especially those with marginal sexualities. The private nature of lesbian sexuality in heteropatriarchal society can make streets sites of colonization (Munt, 1995; Valentine, 1996). More recent research into this question, however, illustrates that this interpretation is reductionist. Like other disenfranchised social and ethnic groups (Diaz, 1995), the accessibility and publicity of neighborhood streets make them important sites of social interaction and citizenship for lesbians (Rothenberg, 1995; Valentine, 1996). As Valentine (1996) argues, the lesbian occupation of the streets can, moreover, reveal the fragility of the heterosexual definitions of space by disrupting a coherent relationship between anatomical sex, sexuality, and gender identity (Bondi, 1998). Valentine (1996) demonstrates how forms of social interaction (public demonstrations of affection), the lesbian presentation of self (clothing, movement, hair styles), and the presence of lesbian cultural icons in public space can actually queer "the heterosexual street." Not all streets, however, have the same characteristics. Brossard's emphasis on "frontiers" suggests that the fragmentation of heteropatriarchal relations is more pronounced along border zones where hierarchies of identity are rearranged.

\section{THE MARGINS OF THE CITY: BOULEVARD SAINT-LAURENT}

Boulevard Saint-Laurent developed as the primary north-south artery of the city of Montréal in the nineteenth century. Due to its location within the economic and sociocultural geography of Montréal, it has developed particular characteristics. By the end of the nineteenth century, it became the civic and symbolic division between
East and West Montréal, more specifically, between the Anglo-capitalist city in the west and the predominantly working-class, French-Catholic parishes in the east. While there have been many exceptions to this division, Boulevard Saint-Laurent's border status has had material outcomes. It has developed as an interstitial space, a receptive "between" space where social and "ethnic" groups that do not fit into the city's imagined binary have created social worlds. Over the course of the twentieth century, as new immigrants moved into the surrounding districts and created commercial and institutional enclaves along the street, Boulevard Saint-Laurent developed as Montréal's "multi-ethnic" corridor. Parts of the boulevard have also historically been the domain of transient populations, the red light district, the garment industry, and popular entertainments. Class, political affiliation, and marginal female identities have, therefore, also been associated with Montréal's border zone.

The interaction with differences is central to the dynamic occurring on the sidewalks of Boulevard Saint-Laurent. Although it extends from the southern to the northern shores of the Island of Montréal, this dynamic is localized in the "ethnic" shopping district between Prince-Arthur Street and Mont-Royal Avenue. Over the course of the twentieth century, this area has been occupied by the widest variety of populations and activities and has endured the most intensive usage. My research shows that while it is not a "queer" or "lesbian" territory, the hybridity and diversity of this portion of the street attracts a lesbian clientele. St-Denis Street a few blocks east and, more recently, the Village gai along Ste-Catherine Street East have been more important sites of lesbian nightlife. Along this portion of Boulevard Saint-Laurent, however, a multiplicity of bodies, desires and identities come into mobile contact. This mobility is heightened by the fact that this is a vibrant commercial street where the economic activities are as diverse as the human traffic that parades along its sidewalks. The combination of industry, artistic production, residence, multinational boutiques, family-run specialty shops, up-scale restaurants, and grungy bars draw a broad-based and diversified clientele to the street. While some populations are associated with the street through residence, work, or community membership, there can never be a singular or dominant definition of the area as 
the territory of any one subcultural group (Allor, 1997; Podmore, 1999). This diversity is often comprised of polar opposites; extremes of wealth and poverty, new and old, chic and shabby, masculine and feminine, and heterosexual and homosexual coexist along this portion of the street. As will be shown, this breakdown in the boundaries between the marginal and the hegemonic makes it possible for lesbians, a population lacking in public space, to mobilize their subjectivity and desires in their everyday travels along this street.

Boulevard Saint-Laurent runs through the western portion of the Plateau Mont-Royal neighborhood. Lesbians have a long-standing relationship with the Plateau MontRoyal District as a place of residence. Politicized lesbians have been creating and appropriating space in this district since the 1970s. Lesbians have found the area attractive for many reasons, such as the concentration of non-traditional family households and practical concerns of centrality and affordability. While it has not housed a specifically lesbian institution since the 1970s, Boulevard SaintLaurent is part of everyday life in the neighborhood. It is a site of leisure and consumption for these households, appreciated for the bargains of its clothing factory outlets, bulk food stores, cheap taverns and restaurants, for the "old world" character of its specialty shops, and for its cafes and art galleries. For the residents, this shopping street is both a practical site of household consumption and a site of urban exploration. Without venturing far from their homes, residents can experience urban tourism by venturing into a site where they make haphazard contact with a broader urban public that often includes other lesbians.

The lesbian geographies presented in the following narratives, however, were spatially limited along the Boulevard. PrinceArthur Street represented a southern boundary zone for the women in the sample. The area between Prince-Arthur and Sherbrooke streets has been subject to intense levels of reinvestment which have created a landscape of upscale bars, restaurants, and multinational clothing stores. Although some of the women interviewed occasionally patronized these spaces, they saw this portion of the street as dominated by wealthy heterosexuals. In their descriptions of their activities, it was clear that they spent most of their time between Prince-Arthur and Rachel Streets, at the center of the old "ethnic" shopping corridor. Although the queer presence is not explicit in this area, the women interviewed identified key anchor points and specific cafes, bars, and restaurants that are seen as lesbian friendly spaces. The area also houses a number of queer institutions such as the city's gay, lesbian, and feminist bookstore, gay pride and film festival organizations, and the provincial gay archives. The presence of these institutions not only demonstrates the importance of Boulevard Saint-Laurent within the queer geography of Montréal, but also attests to a continued receptiveness of difference along this portion of the street. That portion of the Boulevard was the area that the women perceived to be both most diverse and open, and a public space where lesbian visibility was most pronounced.

\section{LESBIAN DESIRE AND CITY LIFE: EXPEDITIONS INTO EVERYDAY SPACE}

How did the women in the sample perceive this street and why were they attracted to explore the area? The majority interpreted Boulevard Saint-Laurent as an open rather than an inclusive place. The openness of the site was linked to certain factors. They described it as an attractive site for urban exploration because of the ethnic diversity of its shops and the populations that create space along the street: "C'est comme je disais, la diversité des gens, le côté ethnique, une boutique à l'autre, qu'elle soit hongroise, zagreb, portugaise, polonaise, [ou] juive. C'est ces gens qui font la place aussi. [C'est] un côté ouvert" (Irène, mid-30s, unemployed). Most characterized this portion of the street as a place that has historically been populated by Eastern and Southern European immigrant populations, but they also included more recent immigrant groups to Montréal such as South and North Asians, West Indians, and Africans. The traditional multiethnic diversity of the street was the most dominant evidence of social diversity, but other social differences were also associated with this space; middle-class inner-city residents rejecting suburbia, youth subcultures, and gays and lesbians added a second layer of diversity to their perceptions. The street was seen as a shared margin. As one woman stated: "[...] I'm not sure it's anymore a queer space than it is a Portuguese space, or an East Indian space. It's

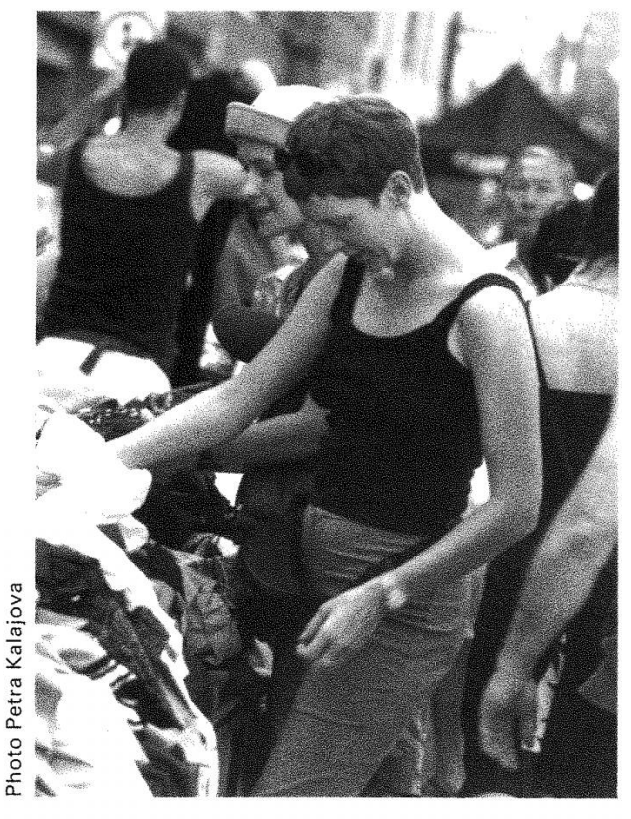

Shopping the Main.

a space that's shared" (Robyn, mid-20s, student). Lesbians were seen, therefore, as one subcultural group that comprises the heterogeneous mix along Boulevard Saint-Laurent. The identification with the space, moreover, was slightly more pronounced among Anglophones and Allophones who generally live in closer proximity to the street and have stronger links to other subcultural groups that concentrate in the area.

While ethnic and social diversity does not necessarily erase heteropatriarchal relations of power that render lesbians invisible, the lack of a singular definition seems on some level to disrupt the hierarchies of difference that determine other urban spaces. Many of the women interviewed articulated this characteristic by describing the street as a place where there is no common denominator. Here, they experience city life on a broad scale and find a place in which they carve out their own niche in urban public space. Regardless of whether populations along Boulevard Saint-Laurent interact or are aware of each other, they coexist under conditions of "unassimilated otherness," social interaction based on the coexistence but not incorporation of differences (Young, 1990). Due to its lack of definition, Boulevard Saint-Laurent was perceived as a particularly accessible site, especially for those populations who generally have difficulty making an impact on public space. The presence of other, interrelated alternative 
populations, moreover, seemed to compound its association difference. Martha's (late 20s, dancer) description of the street reflects these dynamics: "Saint-Laurent is so full of 'freaks' that you' re never the weirdest one there."

The presence of a wide range of marginal groups also makes this street a place where individual ethnic and sexual identities can be integrated. Unlike queer sites, these women valued the area as a place where they experience more than one aspect of their identity. The multiplicity of this street, they reported, enabled them to construct and experience multiple selves. Along Boulevard Saint-Laurent, they interact with the crowd as lesbians, but also as women, and as subjects with ethnic and linguistic identities. Like any other tourist experience, confronting ethnic, social, and sexual diversity served to highlight the differences and commonalties found within the crowd. Such experiences were not described as fragmentation and disruption, as others have depicted the experience of modern urban life (Berman, 1982; Lofland, 1973). Rather, social interaction along Saint-Laurent accommodated an integration of multiple identities that are often subsumed where more limited definitions of belonging dominate. This factor was particularly important to their participation with the street because it allowed for the integration of a lesbian subjectivity with other aspects of identity: "You escape the ghetto of being in the Village where everybody assumes that you're a lesbian and nothing else. You can go to SaintLaurent Street and be a lesbian and be so much more, it seems to me, than just a lesbian. It's where I feel the most comfortable with all the things that I am" (Asha, late 20s, professional).

The possibility of multiplicity seems to have been central to the expression of an autonomous sexuality among women (Wilson, 1991). First, in a place where all aspects of identity are called into question, a singular definition of "woman" is impossible. The presence of a diversity of female identities ranging from traditional to forms of female masculinity and androgyny undermines coherent arrangements between sex, gender, and sexuality. Secondly, multiplicity also served to undermine dominant forms of lesbian identity. For example, the multiplicity of this site was particularly important for lesbians of color. Boulevard Saint-Laurent was seen as a more diverse space where lesbians of color felt comfortable with the multiple aspects of their personal identities: "In the Village, of course I feel like a lesbian, but I feel like a lesbian of color. There aren't very many people of color there. I think the mix of skin types on Saint-Laurent is more diverse than it is in the Village (Janice, late 20s, student). Being visible as a lesbian was possible, and it did not lead to the separation of sexual identity from ethnic identity, a condition that often occurs in more homogeneous lesbian and gay spaces.

What also differentiates the lesbian experience of Boulevard Saint-Laurent from their experiences of queer or lesbian spaces is their everyday movement through and use of the site. Most women ventured here to shop for affordable food, clothing, and household goods, but also to "hang out," or have coffee, dine and drink with friends. By repeatedly occupying the street in ordinary contexts, lesbians have produced places where they circulate and interact with each other and a wider urban public, creating the possibility for a lesbian identity that extends beyond the night world of bars and the temporary space of political actions and parades. This was especially the case for those who live in close proximity to the street. "To me St. Lawrence is one [street] that helps you connect your sexual orientation to your daily living. It's where you go buy your groceries. It's where you go have breakfast with your partner and your friends. It's where you do your everyday things, but you're able to do it as an out lesbian" (Robyn, late 20s, student). For a sexual subculture that revolves fleeting, liminal moments of communal contact in bar spaces and nightclubs or contained spaces, such as women's centers and other women's homes, haphazard social contact along the street also plays an important role in the production of lesbian subjectivity and desire. Even for those who lived further afield, Saint-Laurent was described as a place that was valued for haphazard contacts made in an everyday context. It was seen as a place where lesbians stumble upon each other in the daylight, where they stop and talk to acquaintances and friends, and visually acknowledge those that they only know by sight.

These narratives also demonstrated that desire circulates among lesbians through everyday social interactions and in relation to the possibilities attached to street.
Although overt questioning with regard to "cruising" did not elicit a response, many of the women in my sample described "desire" as central to their experience. Francophone participants were particularly hesitant to describe their exploration of the street as attempts to "drag" or as a form of flanage perhaps because of the connotations of these terms in the French language. Haphazard encounters with strangers and acquaintances along the street were, however, seen as liberating, perhaps because they occurred beyond the confines of protected, private spaces. The expression and exchange of desire between women was at least seen as a possibility along the street. As Nicole (early 30s, government employee) described it,

\section{[...] sur Saint-Laurent, on a un certain contact. Pas nécessairement physique, mais [...] c'est sûr que $c$ 'est plaisant de marcher sur une rue où tu peux, où c'est permis de sourire à une femme, [...] d'aller sur une rue où tu peux rencontrer quelqu'un. C'est ça qui est intéressant. Sur Saint-Laurent, c'est facile.}

Unlike lesbians in bars or at private parties, their engagement with desire along Boulevard Saint-Laurent is more haphazard. They catch each other's eyes while doing mundane tasks like shopping, or while strolling along and merging with the traffic of the street. As in any public space, the familiar "gayze" was the primary clue to the presence of other lesbians on the street, but there are also important visual clues to their desire and identity: "Il y a un regard, une attitude de la personne, c'est ça. Une façon que les gens te regardent, une façon comment elles sont habillées, comment elles sont coiffées, l'attitude, la démarche, les petites choses comme ça" (Irène, mid-30s, unemployed). Although there are codes for detection, for most women, this mixed environment still poses problems. As we move away from the separatism of earlier decades and embrace the multiplicity of the city, an "authentic" lesbian aesthetic and subjectivity is less and less possible.

This uncertainty was particularly important in their descriptions of strolling along the Boulevard. First, some of the participants stressed the importance of negotiation in their exchanges with other women. They described negotiating between the anomie of the crowd, the presence of other women, 
and heterosexual limits to behavior in public space. The tension between uncertainty, visibility, and possibility were common in interviews. Secondly, the uncertainty of urban exploration also undermined the notion of a singular object of desire for queer women. Some of the women reported never being sure if the women they saw on Saint-Laurent were lesbians or not. Some accounted for this by explaining that here even heterosexual women were not typical women. Along Boulevard Saint-Laurent, lesbians share space with women from other countercultural communities, which blurs gender identities and contributes to the circulation of desire in the space. Lesbian desire is mobilized as lesbians occupy space, look, smile, and become part of the uncertain exchange that occurs amidst the traffic of the street. The presence of other women who resist existing norms of heterosexual female behavior and presentation fill the street with as many possibilities as uncertainties. Like other aspects of identity along this street, uncertainty complicates gender identity, making it possible for lesbian desire to move beyond the confines of the late-night bar room and circulate in the afternoon sunlight of the street.

\section{CONCLUSION}

This study seeks advance and understanding of the importance of neighborhood public spaces for the expression of lesbian subjectivity and desire. I have argued neighborhood commercial streets can be meaningful sites of social interaction, community building, and identity. More abstractly, the objective has been to open the city to the expression of lesbian desire and subjectivity by going directly into its streets. Using the narratives of inner-city Montréal lesbians, this paper is, therefore, an attempt to describe "la ville habitée autrement." Narratives of daily travels along this street highlight three very important relationships between lesbian subjectivity and urban space. First, ruptures in the fabric of the heteropatriarchal city can be significant sites for the disruption of norms of gender and sexuality. Although it is never foundational to the definition of the space, lesbian desire circulates along Boulevard Saint-Laurent because it is a place where established codes of gender and sexual identity are called into question by a variety of subcultural groups. Secondly, these narratives demonstrate the importance of heteroge- neity to the expression of lesbian desire and subjectivity. The copresence of differences, particularly of alternative subcultures, led to the rearrangement of hierarchies of identity along the street. In a space with few queer institutions, they participate in the social dynamic of the street as lesbians, sharing this border zone with a variety of others. Finally, unlike bars or queer districts where sexual identity is highlighted, Boulevard Saint-Laurent afforded the integration of other aspects of identity that are central to the everyday experience of urban life. Through their

\section{BIBLIOGRAPHY}

Adler, S., and J. Brenner (1992), "Gender and Space: Lesbians and Gay Men in the City", International Journal of Urban and Regional Research, 16 (1), p. 24-34.

Allor, M. (1997), "Locating Cultural Activity: the 'Main' as Chronotope and Heterotopia", Topia, 1 (1), p. 42.

Berman, M. (1982), All That Is Solid Melts into Air: The Experience of Modernity, New York, Penguin.

Bondi, L. (1998), "Sexing the City", R. Fincher and J. M. Jacobs (eds.), Cities of Difference, London, Guilford Press, p. 177-200.

Bouthillette, A-M. (1998), "Queer and Gendered Housing: A Tale of Two Neighbourhoods in Vancouver", G. B. Ingram et al. (eds.), Queers in Space: Communities, Public Spaces, Sites of Resistance, Seattle, Bay Press, p. 213-232.

Brossard, N. (1980), Le sens apparent, Paris, Flammarion.

Brossard, N. (1974), French Kiss : étreinte-exploration, Montréal, du Jour.

Brossard, N. (1973), Sold-Out : étreintefillustration, Montréal, du Jour.

Diaz, D.R. (1995), "Public Space and Culture: A Critical Response to Conventional and Postmodern Visions of City Life", A. Darder (ed.), Culture and Difference: Critical Perspectives on the Bicultural Experience in the United States, Westport, CT, Bergin and Garvey, p. 123138.

Forsyth, L. H. (1988), "Errant and Air-Born in the City", The Aerial Letter, M. Wildeman (trad.), Toronto, Ontario, The Women's Press, p. 9-26.

Golding, S. (1993), "Quantum Philosophy, Impossible Geographies and a Few Small Points about Life, Liberty and the Pursuit of Sex (all in the name of democracy)", M. Keith and S. Pile (eds.), Place and the Politics of Identity, London, Routledge, p. 206-219.

Gould, K. (1982), "Spatial Poetics, Spatial Politics: Québec Feminists on the City and the interpretations, it is possible to view the intersections between sexuality, gender, class, linguistic, and ethnic identities as these individuals move through the spaces of the street.

Julie Podmore received a doctorate in Geography from Mc Gill University. She currently holds a post-doctoral fellowship in Urban Studies at the Université du Québec à Montréal.

Un comité de lecture a lu et accepté ce texte



Countryside", American Review of Canadian Studies, 12 (1), p. 1-9.

Lofland, L. (1973), World of Strangers: Order and Action in Urban Public Space, New York, Basic Books.

Munt, S. (1995), "The Lesbian Flâneur", D. Bell and G. Valentine (eds.), Mapping Desire: Geographies of Sexualities, London, Routledge, p. 114-125.

Peake, L. (1993), "Race and Sexuality: Challenging the Patriarchal Structuring of Urban Social Space", Environment and Planning. D: Society and Space, 11 (4), p. 415-432.

Podmore, J. (1999), St. Lawrence Blvd. as "Third City": Place, Gender and Difference along Montréal's "Main", Unpublished dissertation (Geography), McGill University.

Potvin, C. (1995), "Écrire (dans) la ville : la Métropolis au féminin", Tangence, 48, p. 84-96.

Rose, G. (1993), Feminism and Geography: The Limits of Geographical Knowledge, Minneapolis, University of Minnesota Press.

Rothenberg, T. (1995), “And She Told Two Friends': Lesbians Creating Urban Social Space", D. Bell and G. Valentine (eds.), Mapping Desire: Geographies of Sexualities, New York, Routledge, p. 165-181.

Valentine, G. (1996), "Renegotiating the 'Heterosexual Street:' Lesbian Productions of Space", N. Duncan (ed.), Body Space: Destabilizing Geographies of Gender and Sexuality, New York, Routledge, p. 146-155.

Valentine, G. (1995), "Out and About: Geographies of Lesbian Landscapes", International Journal of Urban and Regional Research, 19 (1), p. 96-111.

Wekerle, G. R. (1984), “A Woman's Place Is in the City", Antipode, 16 (3), p. 11-19.

Wilson, E. (1991), The Sphinx in the City: Urban Life, the Control of Disorder and Women, London, Virago.

Young, I. M. (1990), Justice and the Politics of Difference, Princeton, Princeton University Press. 